\title{
REEZE-DRYING IMPACT ON HARDNESS OF SELECTED SOFT FRUIT LIOPHILISATES
}

Marek Domin ${ }^{\mathrm{a}}$, Magdalena Ćwiklińska ${ }^{\mathrm{b}}$, Małgorzata Góral-Kowalczyk $\mathrm{c}^{*}$

a Department of Biological Bases of Food and Feed Technology, University of Life Sciences in Lublin, e-mail: marek.domin@up.lublin.pl, ORCID 0000-0002-8389-2811

b Department of Mathematics and Informatics, University of Life Sciences in Lublin, e-mail: magda.cwiklinska@up.lublin.pl, ORCID 0000-0001-7497-7314

c Department of Agricultural, Forestry and Transport Machines, University of Life Sciences in Lublin, e-mail: malgorzata.goral-kowalczyk@ up.lublin.pl, ORCID 0000-0003-0665-5828

*Corresponding author: e-mail: malgorzata.goral-kowalczyk@up.lublin.pl

\begin{tabular}{l}
\hline ARTICLE INFO \\
\hline Article history: \\
Receeved: August 2021 in \\
Received in the revised form: \\
September 2021 \\
Accepted: October 2021 \\
\hline Keywords: \\
pomaces, \\
lyophilization, \\
hardness, \\
water content \\
\\
\hline
\end{tabular}

ABSTRACT

The objective of the paper was to describe the impact of freeze-drying conditions on hardness of lyophilizates obtained based on soft fruit pomace. Raspberry, cherry, and grape pomace from the pressing process carried out with a low-speed rotary press constituted a research material. Immediately after the pressing process, pomaces were placed in forms, frozen, and after freezing they were freeze-dried in the pressure of 20, 42, 63, 85 and $110 \mathrm{~Pa}$. The obtained lyophilizates were subjected to the measurement of hardness with the use of texture meter equipped with a penetrometer in the form of a cone with a vertical angle of $30^{\circ}$. The increase of pressure during freeze-drying of samples was accompanied by the increase of hardness of the obtained lyophilizates, which may affect the energy consumption of the grinding process and the nature of rehydration of the final product. Moreover, the water content of raw material, pomaces, and lyophilizates was determined. The obtained results of measurements were subjected to a statistical analysis which showed that the pressure of freeze-drying significantly diversifies the hardness of the obtained lyophilizates.

\section{Introduction}

Presence of a relevant number of vegetables and fruit that are a source of carbohydrates, many vitamins, mineral resource, fibre, and antioxidants reducing free radicals' amount in a body, takes the second position in the food pyramid after physical activity. Regular consumption of vegetables and fruit is crucial in prevention of diseases known as lifestyle diseases (type 2 diabetes, obesity, hypertension, coronary heart disease, cancer) (Ziółkowska et al., 2019; Niszczota et al., 2020). Extensive studies showed that food supplements cannot cover the body need of nutrients that are supplied with fruit and vegetables. Furthermore, if the number of supplements taken is too high, it may lead to deterioration of health (Konopacka et al., 2018). A range of food products made of fruit and vegetables, offered by 
industry, includes ground fresh fruit, jams, frozen products, dried products, granulated mixtures, pomaces, and juices (Neves et al., 2011; Sinha et al., 2012).

Juices as versatile products are designated for clients of all ages, from children to seniors (Plocharski et al., 2017). In the process of obtaining raw juice (must), waste substances, known as pomace, remain. Their share is from 10 to $35 \%$ of the initial mass of the processed raw material (Kumider, 1996; Tarko et al., 2012; Wichrowska and Żary-Sikorska, 2015). The Polish fruit and vegetable industry has ca. 260 thousand tons of fruit pomace which it has to manage (Kapusta, 2016). Depending on the type of fruit and technology of obtaining juice, there is a varied content of organic, mineral substances and up to $73 \%$ of water (Kumider, 1996; Tarko et al., 2012). A high content of water favours rapid development of micro-organisms that initiate the fermentation and decomposition processes. When pomaces are properly processed, they can be used further since they are a rich source of many valuable nutrients (carbohydrates, mineral compounds, pectins, fibre, vitamins, colouring and aromatic substances) (Si et al., 2015). The future of pomace lies in the processing of their great amounts to the form of useful products and conversion to the form of useful components (Górnicki, 2011). Presently, fruit and vegetable pomaces are the most often used in the feed industry. A high content of organic acids, sugars, fatty substances, fibre, and vitamins causes that pomace has become an attractive feed raw material (Shalini and Gupta, 2010). Pomace may be an efficient raw material for biogas production in anaerobic processes of their processing. As much as $80 \%$ of organic matter of pomace may be converted into biogas with the energy value of $10-30 \mathrm{~W} \cdot \mathrm{m}^{-3}$ (Tarko et al., 2012). Pomace may become an important source for obtaining biofuel by means of fermentation of sugars to ethanol. It is also a rich source of fibre, which, when properly prepared, may become an important supplement of a healthy diet that reduces the risk of diabetes, atherosclerosis, heart diseases and some cancers. Pomaces from some fruits are a significant source of pectins. Pectins are used in the food industry as a gelling, compacting and stabilizing addition for food products (Mitek et al., 2014). Extracted pomace may be used for obtaining natural dyes and aromas. Natural dyes occur mainly in the fruit skin, whereas pomace from berry fruit is their best source. Pomace includes a considerable number of compounds with a strong antioxidant activity (betalains, polyphenols, etc.). Dried and powdered pomace is added to food products e.g., yoghurt, icecreams, they may improve pro-healthy value and sensory properties of those products (Barba et al., 2015). For example, during pressing of carrot juice from 60 to $80 \%$ of carotenoids included in carrot do not get to the juice and remain in pomace (Tarko et al., 2012; Nadulski et al., 2013). Natural dyes, aromas, antioxidants, and vitamins play a crucial role in the correct feeding of a man. Bioactive substances are thermolabile as a rule, which causes that thermal processing caused their degradation (Kunachowicz et al., 2017). The use of freeze-drying for preservation of pomace is a method for their long-term storage and then defragmentation to a relevant fraction without the loss of valuable elements (Sharif et al., 2017). The use of pomace as a micro-biological substrate e.g., for bacteria that produce lactic acid is an interesting alternative for managing pomace (Doroški et al., 2021). Pomace with a high content of simple sugars and organic acids may be used in such a way (Górska and Mendrycka, 2006). Knowledge concerning physico-chemical properties of particular pomaces causes that even more efficient technologies of their use are being developed (Kelley et al., 2018; Sagar et al., 2018).

The objective of the paper was identification of the nature of changes in hardness of lyophilizates based on the selected soft fruit pomace in relation to the pressure conditions of 
Reeze-drying impact...

their sublimation drying. The scope of the paper covered obtaining of raspberry, grapes and cherry lyophilizates in the sublimation drying process under the pressure of $20,42,63,85$ and $110 \mathrm{~Pa}$, determination of the kinetics of freezing of the investigated raw materials during initial freezing, determination of the water content of samples on particular stages of the research and measurement of the hardness of the final product.

\section{Material and methods}

Pomaces obtained immediately after pressing with a low-speed rotation press obtained from the following soft fruit were subjected to investigation:

- raspberry - Polesie cultivar,

- grapes - Cascade cultivar,

- cherry- Łutówka cultivar.

Measurements and analyses were performed based on the flow chart developed as a part of methodology (Fig. 1).

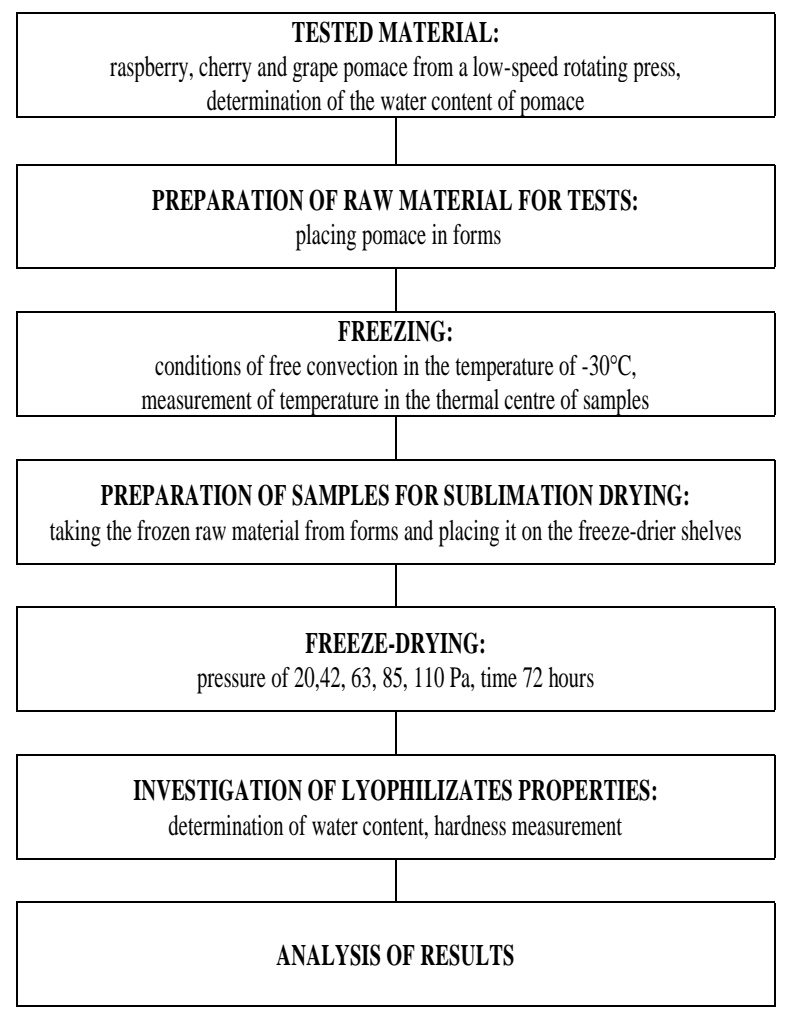

Figure 1. Flowchart of the research and measurements process 
Immediately after pressing and indispensable measurements, the investigated material, was placed in polycarbonate form for production of ice and then frozen in the condition of natural convection of air in the temperature of $-30^{\circ} \mathrm{C}$ in order to prevent biochemical and microbiological changes caused by fermentation or spoiling. The use of polycarbonate forms enabled obtaining uniform cuboid-shaped samples with dimensions of $3 \times 3 \times 5 \mathrm{~cm}$.

Determination of the water content was performed on fresh fruit after pressing and freezedrying in five iterations, finding the result being an average from the performed measurements. The water content was determined according to the guidelines of the standard PN-ISO 1026:2000 when the sample mass was $50 \mathrm{~g}$ determined with a precision $\pm 0.01 \mathrm{~g}$. The water content was expressed in percentage shares.

Measuring probes PT 100 cooperating with a meter MPI-L which registered changes of temperatures in five iterations, were placed in the selected samples (in the thermal centre) before freezing. The objective of the temperature measurement was obtaining freezing curves based on which values of freezing kinetics was calculated. For calculation of the freezing time and speed the following formula were applied (Bøgh-Sørensen, 2006):

$\mathrm{T} \quad-$ freezing time,

$$
\mathrm{T}=\mathrm{T}_{2}-\mathrm{T}_{1}(\mathrm{~min})
$$

$\mathrm{T}_{1} \quad$ - time needed to obtain a set temperature of the cooled sample $\left(15^{\circ} \mathrm{C}\right)$,

$\mathrm{T}_{2} \quad$ - time, after which, the sample obtained the set temperature in the thermal centre $\left(-20^{\circ} \mathrm{C}\right)$.

$\mathrm{v} \quad-$ freezing speed,

$$
\mathrm{v}=\frac{\mathrm{s} \times 0,5}{\mathrm{~T}}\left(\mathrm{~mm} \cdot \mathrm{h}^{-1}\right)
$$

s - characteristic dimension of a sample, $(\mathrm{mm})$

$\mathrm{T} \quad$ - freezing time, (h)

The frozen samples were freeze-dried in Christ Alpha 2-4 device LDplus for 72 hours in the pressure of: $20,42,63,85$ or $110 \mathrm{~Pa}$. In the industrial practice the stage of sublimation drying is performed within the scope of 60-70 Pa (Rząca and Witrowa-Rejchert, 2007; Ciurzyńska et al., 2011). Structural parameters of the freeze-drier enabled to obtain recommended values of pressure (62 Pa) and to compare lower (20 and $42 \mathrm{~Pa}$ ) and higher (85 and $110 \mathrm{~Pa}$ ) values used for drying. When the freeze-drying process is finished hardness is measured. Hardness was measured on LFRA 4500 Brookfield device and the following parameters were maintained (Baryłko-Pikielna, 1975; Baryłko-Pikielna, 2009): head travel speed $0.5 \mathrm{~mm} \cdot \mathrm{s}^{-1}$, cone-shaped indenter with $30^{\circ}$ angle, sampling time 100 measurements $\cdot \mathrm{s}^{-1}$, minimum force of contact of an indenter with a sample $0.01 \mathrm{~N}$, precision of measurement 0.01 $\mathrm{N}$ and translocation of an indenter $5 \mathrm{~mm}$. Hardness was expressed in newtons (N) assuming an average maximum pressure force on the indenter from nine measurements.

Statistical analyses were carried out with STATISTICA 13. Shapiro-Wilk test was applied for the normality test, and Brown-Forsyth test for testing the uniformity of variance. To check whether there are significant differences between the investigated groups, the $\mathrm{F}$ test of analysis of variance (ANOVA) and then the Tukey's test of simultaneous comparisons were applied. 


\section{Results and discussion}

The water content is a factor that shapes many properties of raw material. Fresh fruit and vegetables include ca. 70-95\% of water, the amount of which besides the temperature is the main factor that determines the shelf life of many products (Reißner et al., 2019; Zhou et al., 2019). Results of measurement of the water content in raw material, pomace, and freezedried pomace showed that the average water content in the investigated raw material was within the range from $80.8 \%$ (grapefruit) to $82.9 \%$ (cherry fruit) (Table 1).

Table 1.

Average water content in the investigated material

\begin{tabular}{ccccc}
\hline \multirow{2}{*}{ Item } & \multirow{2}{*}{$\begin{array}{c}\text { Raw } \\
\text { material }\end{array}$} & \multicolumn{2}{c}{ Average water content $(\%) \pm$ standard deviation } \\
\cline { 3 - 5 } & Fruit & Pomace & Lyophilizate \\
\hline 1 & grapefruit & $80.8 \pm 0.3^{\mathrm{a}}$ & $66.1 \pm 1.2^{\mathrm{a}}$ & $9.1 \pm 0.2^{\mathrm{b}}$ \\
2 & raspberry & $82.1 \pm 0.3^{\mathrm{b}}$ & $71.3 \pm 1.1^{\mathrm{b}}$ & $7.7^{\mathrm{b}}$ \\
3 & cherries & $82.9 \pm 0.3^{\mathrm{a}}$ & $11.7 \pm 0.5^{\mathrm{c}}$ \\
\hline
\end{tabular}

$\overline{\text { Statistically significant differences } \mathrm{p}<0.05 \text { statistically uniform groups within a given raw material were marked }}$ with the same letter

The obtained results of determination of the water content confirmed literature data on fruit. The pressing process caused reduction of the average water content in the investigated material from ca. $66 \%$ for grape pomace to over $71 \%$ in case of cherry pomace (Table 1 ). The water content in the investigated pomace was close to the values provided in other papers on the pomace e.g., from apples, kiwi fruit, pineapple, orange, blueberries and other (Selani et al., 2014; Macagnan et al., 2015; Domin et al., 2020).

During the freeze-drying of fruit, in many cases, the presence of the skin constitutes a barrier that impedes or even disables water vapour release. The presence of a great amount of cover tissue in the pomace composition impedes the drying process with both traditional and sublimation methods. Lyophilizates based on particular raw materials, obtained during the studies, contain water from $7.7 \%$ (grape pomace) to $11.7 \%$ (cherry pomace). After the drying time, which was 72 hours, results of water content determination in samples dried in various pressures for a particular raw material had almost identical values which after averaging were assumed as the final water content in a lyophilizate (Table 1).

Results of statistical analysis proved that the percentage water content in raspberry, grape and cherry fruit significantly differs. Similar significant differences between the analysed fruit occur in the water content in pomace and in a lyophilizate.

Simultaneous comparisons (Table 1) proved that the water content in fruit differs significantly between all compared fruit, is the highest for grapes and the lowest for cherry. No statistically significant difference in the water content in raspberry and cherry pomace was reported. Each of the compared fruit has a significantly varied water content in a lyophilizate (Fig. 2). 

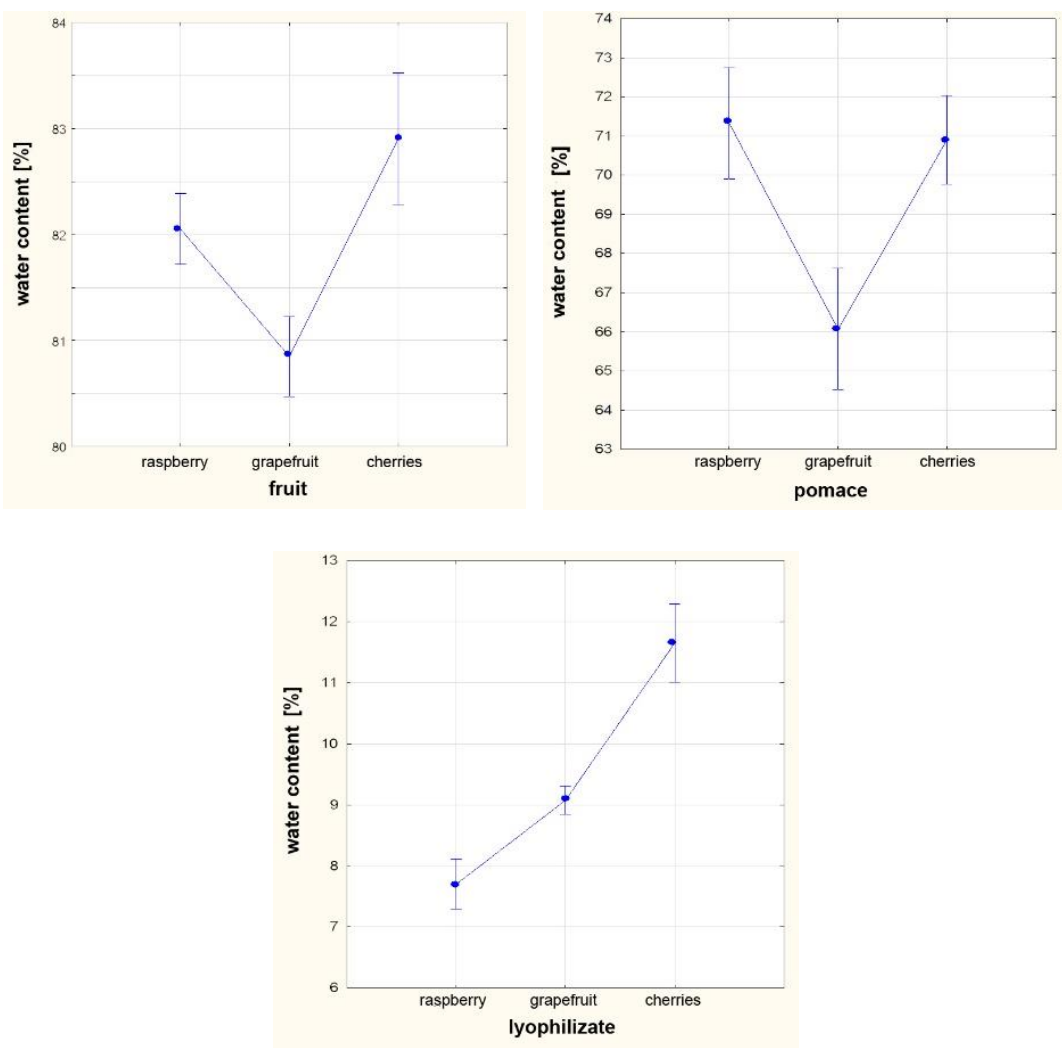

Figure 2. Diagram of average values with $95 \%$ confidence interval of the percentage water content: fruit, pomace, lyophilizate

The applied Shapiro-Wilk normality test did not allow to reject hypotheses on the normality of distribution of each property for particular fruit. To verify the uniformity of variance in the investigated groups, Brown-Forsyth test was applied, and its results confirmed the uniformity of variance of investigated properties. It enabled the application of ANOVA test.

Registration of the temperature change in the thermal centre of the frozen pomace samples enabled obtaining freeze curves, based on which the initial cryoscopic temperature was determined and the freezing speed was calculated (Fig. 3).

The initial cryoscopic temperature determined based on the freezing curves in case of raspberry pomace was $-1.67^{\circ} \mathrm{C},-2.16^{\circ} \mathrm{C}$ of grape pomace and $-2.50^{\circ} \mathrm{C}$ of cherries. The determined cryoscopic temperatures confirmed the results obtained by other plant raw materials researchers who use other research methods (Auleda et al., 2011).

Fruit pomaces were frozen in the same conditions as a result of which it was possible to conclude that the highest speed of freezing was obtained by raspberry pomace and was $8.74 \mathrm{~mm} \cdot \mathrm{h}^{-1}$, the lowest by cherries with the speed of $8.25 \mathrm{~mm} \cdot \mathrm{h}^{-1}$. Grape pomace was freezing with the slowest speed of $6.38 \mathrm{~mm} \cdot \mathrm{h}^{-1}$. 
Reeze-drying impact...

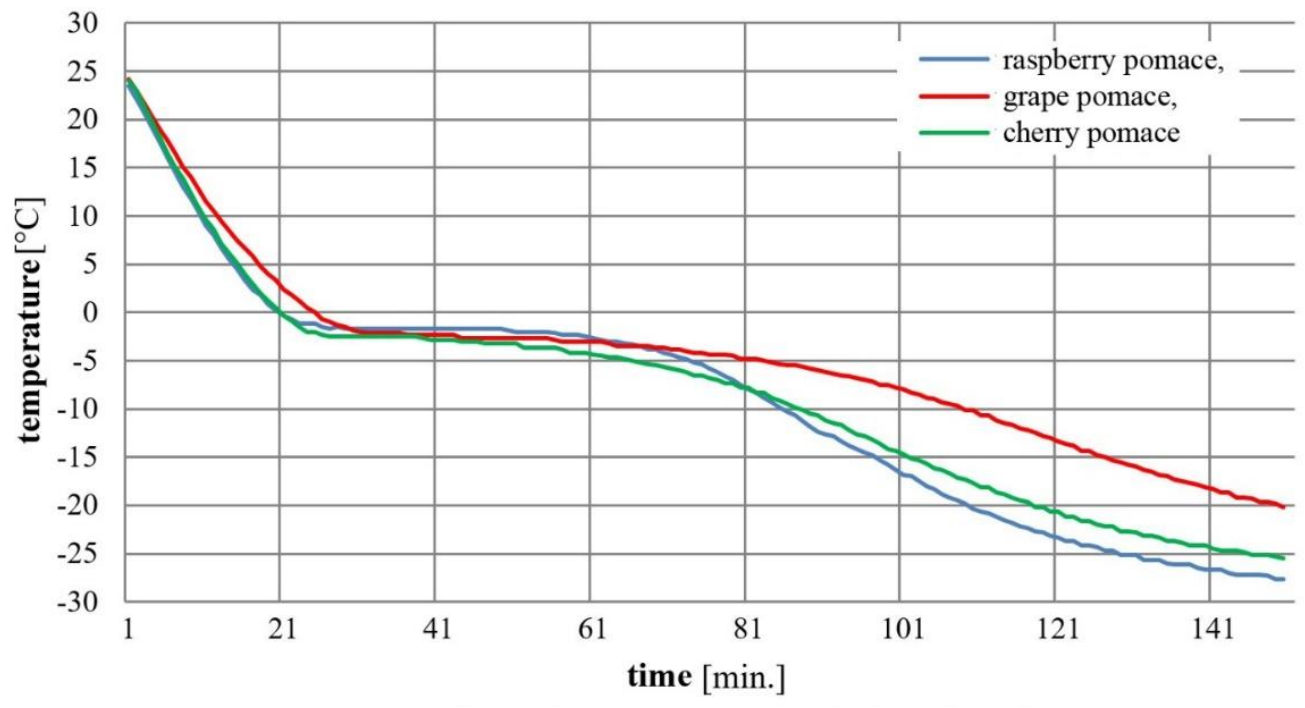

Figure 3. Average curves of freezing of the investigated samples

When applying various pressure values in case of raspberry pomace we obtain a lyophilizate with a significantly various hardness. The highest value of hardness was reported in case of samples dried in the pressure of $110 \mathrm{~Pa}$, the average value of which was $33.53 \mathrm{~N}$. Reduction of the drying pressure was related to reduction of the average hardness of investigated samples from raspberry pomace, which achieved the lowest average value amounting to $14.61 \mathrm{~N}$ for samples dried in the pressure of $20 \mathrm{~Pa}$ (Table 2).

Table 2.

Average hardness of freeze-dried pomace.

\begin{tabular}{lccc}
\hline \multirow{2}{*}{$\begin{array}{l}\text { Pressure } \\
\text { of drying }(\mathrm{Pa})\end{array}$} & \multicolumn{3}{c}{ Average hardness of pomace $(\mathrm{N}) \pm$ standard deviation } \\
\cline { 2 - 4 } & raspberry & grapefruit & cherry \\
\hline 20 & $14.61 \pm 0.27^{\mathrm{a}}$ & $14.54 \pm 0.22^{\mathrm{a}}$ & $11.73 \pm 0.73^{\mathrm{a}}$ \\
42 & $17.20 \pm 1.25^{\mathrm{b}}$ & $16.40 \pm 0.41^{\mathrm{a}}$ & $15.21 \pm 0.99^{\mathrm{b}}$ \\
63 & $21.92 \pm 1.37^{\mathrm{c}}$ & $22.29 \pm 0.83^{\mathrm{b}}$ & $20.43 \pm 1.28^{\mathrm{c}}$ \\
85 & $25.13 \pm 1.27^{\mathrm{d}}$ & $25.19 \pm 0.85^{\mathrm{c}}$ & $29.24 \pm 1.39^{\mathrm{d}}$ \\
110 & $33.53 \pm 1.16^{\mathrm{e}}$ & $32.57 \pm 1.80^{\mathrm{d}}$ & $34.25 \pm 1.44^{\mathrm{e}}$ \\
\hline
\end{tabular}

Statistically significant differences $\mathrm{p}<0.05$; statistically uniform groups within a particular fruit were marked with the same letter 
Applying the pressure of $20 \mathrm{~Pa}$ and $42 \mathrm{~Pa}$ in case of grapes, we obtain a lyophilizate with statistically different hardness. The remaining levels of pressure cause that the lyophilizate with significantly different hardness is obtained. The highest average hardness of freezedried grape pomace was reported in case of drying of samples in the pressure of $110 \mathrm{~Pa}$ and it was $32.57 \mathrm{~N}$. The reduction of pressure of freeze-drying was accompanied by successive reduction of the average hardness of samples which dried in the pressure of $63 \mathrm{~Pa}$ obtained hardness of $22.29 \mathrm{~N}$ whereas samples dried in the pressure of $20 \mathrm{~Pa}$ achieved an average hardness of $14.54 \mathrm{~N}$ (Table 2).

Hardness of lyophilizates from cherry pomace was $11.73 \mathrm{~N}$ in case of samples freezedried in the pressure of $20 \mathrm{~Pa}$ and was rising up to $34.25 \mathrm{~N}$ for samples dried in the pressure of $110 \mathrm{~Pa}$. The average hardness of cherry lyophilizates obtained when various pressure values were applied, differ significantly from each other.

From among the investigated lyophilizates the highest average hardness was reported in case of pomaces freeze-dried in the pressure of $110 \mathrm{~Pa}$ and it was $34.25 \mathrm{~N}$ for cherry, 33.53 $\mathrm{N}$ for grapes and $32.57 \mathrm{~N}$ for raspberries (Fig. 4).

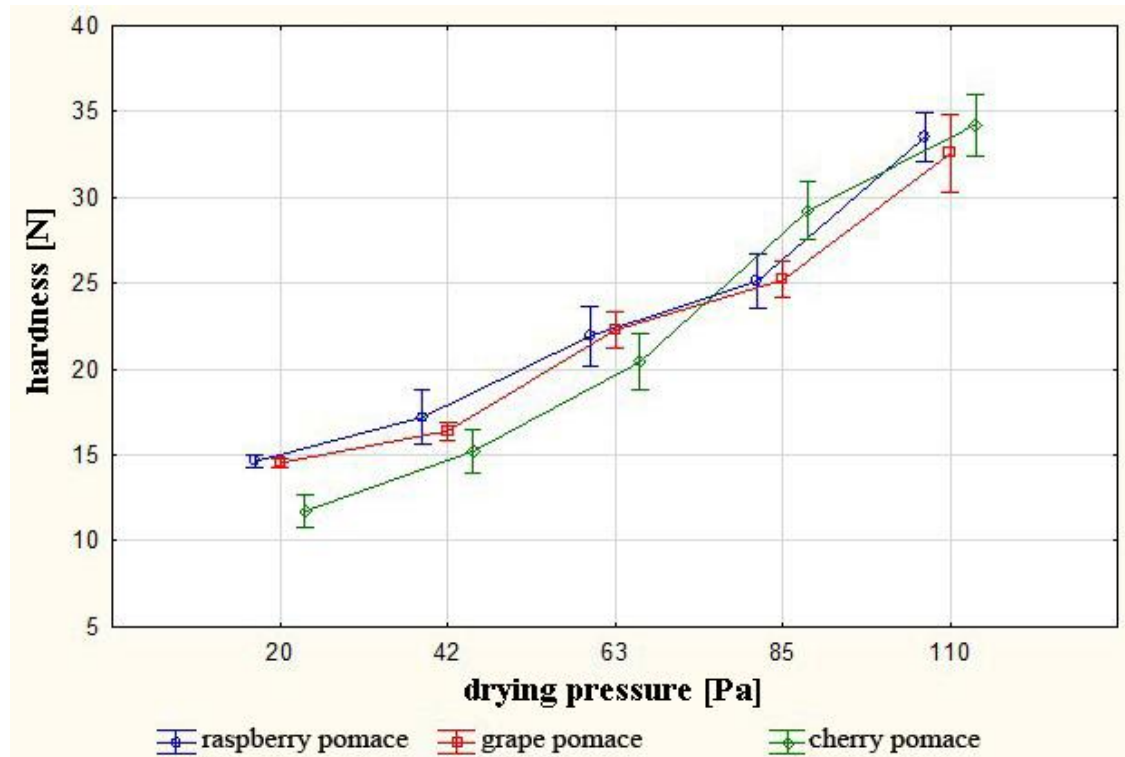

Figure 4. Hardness of raspberry, grapes and cherry lyophilizates in relation to the sublimation drying pressure

Along with reduction of the freeze-drying pressure, a successive decrease in hardness, which obtained the lowest value in case of cherry pomace samples freeze-dried in the pressure of $20 \mathrm{~Pa}$, was reported. A slightly higher hardness value was in case of freeze-dried grape and raspberry pomace achieving respectively $14.54 \mathrm{~N}$ and $14.6 \mathrm{~N}$ after freeze-drying in $20 \mathrm{~Pa}$. 
A statistical analysis of these results was performed. The Shapiro-Wilk test was applied for testing distribution normality, and Brown-Forsyth test for testing the uniformity of variance. Results of the performed tests did not allow rejection of the hypothesis on the distribution normality and uniformity of variance of hardness of freeze-dried pomace of the investigated fruit at specific drying pressure and enables the application of the analysis of variance (ANOVA).

The analysis performed enables that there are significant differences in the hardness of freeze-dried raspberry, grape, and cherry pomace when various pressure values were applied. Multiple comparisons tests were performed to show for each fruit at which level of a factor, namely pressure, we will obtain significantly different results of hardness of freeze-dried pomace.

Measurements of hardness showed that the increase of pressure during sublimation drying is related to obtaining lyophilizates with a higher hardness in case of each investigated materials (Rey and May, 2010; Serna-Cook et al., 2015). The increase of hardness is caused by refracting of the micro-structure of pomace during freeze-drying in higher pressure. The increase of pressure in the working chamber is accompanied by the increase of freeze-drying temperature which is a factor that shapes characteristics of transition of the solid phase to volatile phase (Stępień, 2009; Patel et al., 2010). Structure refracting usually takes place over the boundary of transition from the solid to gas phase which in case of majority of plant tissues takes place above $-45^{\circ} \mathrm{C}$. Similar results were obtained by other authors during fruit and vegetables freeze-drying (Anglea, 1993; Krokida, 1998; Rudy et al., 2015).

\section{Conclusions}

Based on the research and analyses of the obtained results, we made the following conclusions:

1. The freeze-drying method is a very promising method of aggregation, preservation and processing of the waste left after pressing of soft fruit with low-speed rotating presses. Solids formed before freezing maintained a great cohesion at each stage of freeze-drying, storing and duration of measurements. Their integrity enables measurement of the maximum hardness with the use of texture meter.

2. Pressure of the freeze-drying process is a parameter that shapes hardness of the obtained lyophilizates in each of the investigated types of pomaces. Reduction of the sublimation drying pressure was related to reduction of hardness of lyophilizates obtained in these conditions. Intensity of transition of $\mathrm{H}_{2} \mathrm{O}$ from the solid to gas phases and the extend of the boundary of phase transition is related to reduction of the sublimation drying pressure, which influences the microstructure and hardness of a lyophilizate.

3. A high, as for a lyophilizate, water content (from 7.7 to 11.7\%) in the obtained samples results from the presence of the covering tissue (fruit skin) in the mass of the investigated raw material. Covering tissue of fruit (skin) constitutes a natural barrier in removal of sublimate from the lyophilizate raw material. 


\section{References}

Anglea, S.A., Karathanos, V.T., Karel, M. (1993). Low temperature transitions in fresh and osmotically dehydrated plant materials. Biotechnology Progress, 9(2), 204-209.

Auleda, J.M., Raventós, M., Sánchez, J., Hernández, E. (2011). Estimation of the freezing point of concentrated fruit juices for application in freeze concentration. Journal of Food Engineering, 105, 289-294.

Barba, F.J., Puértolas, E., Brncic, M., Panchev, I.N., Dimitrov, D.A., Athès-Dutour, V. (2015). Food waste recovery: processing technologies and industrial techniques. Academic Press is an Imprint of Elsevier, London, 249-272. ISBN 978-0-12-800351-0.

Baryłko-Pikielna, N. (1975). Zarys analizy sensorycznej żywności. WNT, Warszawa.

Baryłko-Pikielna, N., Matuszewska, I. (2009). Sensoryczne badania żywności. Podstawy - MetodyZastosowania. Wydawnictwo Naukowe PTTŻ, Kraków. ISBN 9788392464693

Bøgh-Sørensen, L. (2006). Recommendations for the Processing and Handling of Frozen Foods. International Institute of Refrigeration, Paris. ISBN 9782913149526

Ciurzyńska, A., Lenart, A., Siemiątkowska, M. (2011). Wpływ odwadniania osmotycznego na barwę i właściwości mechaniczne liofilizowanych truskawek. Acta Agrophysica, 17(1), 17-32.

Domin, M., Dziki, D., Kłapsia, S., Blicharz-Kania, A., Biernacka, B., Krzykowski, A., (2020). Influence of the freeze-drying conditions on the physicochemical properties and grinding characteristics of Kiwi. International Journal of Food Engineering, 16(1-2), 20180315.

Doroški, A., Klaus, A., Kozarski, M., Tomasevic, I., Vunduk, J., Djekic, I. (2021). The influence of grape pomace substrate on quality characterization of Pleurotus ostreatus-Total quality index approach. Journal of Food Processing and Preservation, 45, e15096.

Górnicki, K. (2011). Modelowanie procesu rehydratacji wybranych warzyw i owoców. Wydawnictwo SGGW, Warszawa. ISBN 978-83-7583-325-6.

Górska, C., Mendrycka, M. (2006). Możliwości zastosowania liofilizacji do przedłużania trwałości komponentów biologicznych używanych do produkcji kosmetyków. Medycyna Doświadczalna i Mikrobiologia, 58(2), 169-177.

Kapusta, I. (2016). Właściwości fizykochemiczne winogron oraz win produkowanych w poludniowowschodniej Polsce. Wydawnictwo Uniwersytetu Rzeszowskiego, Rzeszów. ISBN 978-837996297-6.

Kelley, D.S., Adkins, Y., Laugero, K.D. (2018). A Review of the Health Benefits of Cherries Nutrients, 10(3), 368.

Konopacka, D., Rutkowski, K., Płocharski, W. (2018). Owoce $i$ warzywa jako składnik zdrowej diety człowieka. Oddział Małopolski Polskiego Towarzystwa Technologów Żywności, Kraków. ISBN 978-83-946796-1-3.

Krokida, M.K., Karathanos, V.T, Maroulis, Z.B. (1998). Effect of freeze-drying conditions on shrinkage and porosity of dehydrated agricultural products. Journal of Food engineering, 35(4), 369-380.

Kumider, J. (1996). Utylizacja odpadów przemystu rolno-spożywczego. Wydawnictwo Akademii Ekonomicznej w Poznaniu, Poznań. ISBN 83-85530-63-0.

Kunachowicz, H., Przygoda, B., Nadolna, I., Iwanow, K. (2017). Tabele składu i wartości odżywczej żywności. Wydawnictwo Lekarskie PZWL, Warszawa. ISBN 978-83-200-5311-1.

Macagnan, F.T., Santos, L.R., Roberto, B.S., Moura, F.A., Bizzani, M., Silva, L.P. (2015). Biological properties of apple pomace, orange bagasse and passion fruit peel as alternative sources of dietary fibre. Bioactive Carbohydrates and Dietary Fibre, 6(1), 1-6.

Mitek, M., Leszczyński, K. (2014). Wybrane zagadnienia z technologii żywności pochodzenia roślinnego. Wydawnictwo SGGW, Warszawa. ISBN 978-83-7583-576-2.

Nadulski, R., Zawiślak, K., Panasiewicz, M., Strzałkowska, K. (2013). Intensyfikacja procesu tłoczenia soków z wybranych warzyw korzeniowych z zastosowaniem techniki mrożenia. Inżynieria Rolnicza, 1(141), 133-141. 
Reeze-drying impact...

Neves, M.F, Trombin, V.G, Lopes, F.F., Kalaki, R., Milan, P. (2011). World consumption of fruit juices, nectars, and still drinks. The orange juice business: A Brazilian perspective. Academic Publishers, Wageningen. ISBN 978-90-8686-739-4.

Niszczota, S., Dziubiński, K., Kupidura, A., Miziołek, D., Pacuszka, R., Rafa, W., Siestrzewitowska, A. (2020). Produkcja upraw rolnych i ogrodniczych w 2019r. Główny Urząd Statystyczny, Warszawa. ISSN 2353-5180.

Patel, S.M., Doen, T., Pikal, M.J. (2010). Determination of End Point of Primary Drying in FreezeDrying Process Control. AAPS PharmSciTech, 11(1), 73-84.

Plocharski, W., Markowski, J., Groele, B., Stos, K., Koziol-Kozakowska A. (2017). Soki, nektary, napoje - aspekty rynkowe i zdrowotne. Przemyst Fermentacyjny i Owocowo-Warzywny, 61, 6-10.

PN-ISO 1026:2000, Produkty owocowe i warzywne. Oznaczanie zawartości suchej substancji w wyniku suszenia przy obniżonym ciśnieniu i zawartości wody w wyniku destylacji azeotropowej.

Reißner, A-M., Al-Hamimi, S., Quiles, A., Schmidt, C., Struck, S., Hernando, I., Turnerb, C., Rohma, H. (2019). Composition and physicochemical properties of dried berry pomace. Journal of the Science of Food and Agriculture, 99(3), 1284-1293.

Rey, L., May, J.C. (2010). Freeze Drying/Lyophilization of Pharmaceutical and Biological Products. Third edition, Informa Healthcare, London. ISBN-13: 9781439825754

Rudy, S., Dziki D., Krzykowski, A., Gawlik-Dziki, U., Polak, R., Różyło, R. (2015). Influence of pretreatments and freeze-drying temperature on the process kinetics and selected physico-chemical properties of cranberries (Aaccinium macrocarpon Ait.). LWT - Food Science and Technology, 63(1), 497-503

Rząca, M., Witrowa-Rajchert, D. (2007). Suszenie żywności w niskiej temperaturze. Przemyst Spożywczy, 61(4), 30-35.

Sagar, N.A, Pareek, S., Sharma, S., Yahia, E.M., Lobo, M.G. (2018). Fruit and Vegetable Waste: Bioactive Compounds, Their Extraction, and Possible Utilization. Comprehensive Reviewsin Food Science and Food Safety, 17(3), 512-531.

Selani, M.M., Brazaca, S.G.C., Dias, C.T.S., Ratnayake, W.S., Flores, R.A., Bianchini A. (2014). Characterisation and potential application of pineapple pomace in an extruded product for fibre enhancement. Food Chemistry, 163, 23-30.

Serna-Cook, L., Vargas-Munoz, D.P., Aponte, A.A. (2015). Structural, physical, functional and natraceutical changes of freeze-dried fruit. African Journal of Biotechnology, 14(6), 442-450.

Shalini, R., Gupta, D. K. (2010). Utilization of pomace from apple processing industries: a review. Journal of Food Science and Technology, 47, 365-371.

Sharif, Z.I.M., Mustapha, F.A., Jai, J., Mohd.Yusof, N., Zaki, N.A.M. (2017). Review on methods for preservation and natural preservatives for extending the food longevity. Chemical Engineering Research Bulletin, 19, 145-153.

Si, X., Chen, Q., Bi, J., Wu, X., Yi, J., Zhou, L., Li, Z. (2015). Comparison of different drying methods on the physical properties, bioactive compounds, and antioxidant activity of raspberry powders. Journal of the Science of Food and Agriculture, 96(6), 2055-2062

Sinha, N.K, Sidhu, J.S, Barta, J., Wu, J.S.B, Cano, M.P. (2012). Handbook of Fruits and Fruit Processing. John Wiley \& Sons Ltd, New Delhi. ISBN 978-0-8138-0894-9

Stępień, B. (2009). Modyfikacja cech mechanicznych i reologicznych wybranych warzyw pod wptywem różnych metod suszenia. Wydawnictwo Uniwersytetu Przyrodniczego, Wrocław. ISBN 97883-60574-75-1.

Tarko, T., Duda-Chodak, A., Bebak, A. (2012). Aktywność biologiczna wybranych wytłoków owocowych oraz warzywnych. Żywność: nauka-technologia-jakość, 4(83), 55-65.

Wichrowska, D., Żary-Sikorska, E. (2015). Właściwości prozdrowotne jabłkowych wytłoków poprasowych. Inżynieria i Aparatura Chemiczna, 54(5), 286-287. 
Zhou, M., Li, C., Bi, J., Jin, X., Lyu, J., Li, X. (2019). Towards understanding the enhancement of moisture diffusion during intermediate infrared drying of peach pomace based on the glass transition theory. Innovative Food Science and Emerging Technologies, 54(5), 143-151

Ziółkowska, E., Kursa L., Wróblewska, A., Wojciechowski, M., Bogumił, A. (2019). Produkcja $i$ handel zagraniczny produktami rolnymi w 2018 r. Główny Urząd Statystyczny, Warszawa. ISSN 1507-9449.

\title{
WPLYW PROCESU LIOFILIZACJI NA TWARDOŚĆ LIOFILIZATÓW Z WYBRANYCH OWOCÓW MIĘKKICH
}

\begin{abstract}
Streszczenie. Celem pracy było scharakteryzowanie wpływu warunków liofilizacji na twardość liofilizatów uzyskanych na bazie wytłoków z owoców miękkich. Materiał badawczy stanowiły wytłoki z malin, wiśni i winogron, uzyskane po procesie tłoczenia $\mathrm{z}$ wykorzystaniem prasy wolnoobrotowej. Bezpośrednio po procesie tłoczenia wytłoki umieszczano w formach, zamrażano, a po zamrożeniu liofilizowano w ciśnieniu 20, 42, 63, 85 i $110 \mathrm{~Pa}$. Uzyskane liofilizaty poddano pomiarom twardości $\mathrm{z}$ wykorzystaniem teksturometru zaopatrzonego w penetrometr w postaci stożka o kącie wierzchołkowym $30^{\circ}$. Wzrostowi ciśnienia podczas liofilizacji prób towarzyszył wzrost twardości uzyskanych liofilizatów, co może mieć wpływ na energochłonność procesów rozdrabniania i charakter rehydracji produktu końcowego. Dokonano również oznaczenia wilgotności surowca, wytłoków i liofilizatów. Uzyskane wyniki pomiarów poddano analizie statystycznej, która wykazała, że ciśnienie liofilizacji w sposób istotny różnicuje twardość uzyskanych liofilizatów.
\end{abstract}

Słowa kluczowe: wytłoki, liofilizacja, twardość, wilgotność 